\title{
Non-prescription use of Antibiotics and its Associated Factors in Drug Retail Outlet in Ambo Town, Oromiya, Ethiopia: a cross-sectional study
}

Mohammed Bule

Ambo University https://orcid.org/0000-0002-1040-1583

Hika Alemayehu

Rift Valley University

Tesemma Sileshi

Rift Valley University

Eshetu E. Chaka ( $\square$ eejeta@yahoo.com )

Rift Valley University https://orcid.org/0000-0002-4662-9125

\section{Research}

Keywords: Antibiotics, Community pharmacy, drug store, non-prescription, Ambo

Posted Date: January 18th, 2021

DOI: https://doi.org/10.21203/rs.3.rs-145866/v1

License: (c) (i) This work is licensed under a Creative Commons Attribution 4.0 International License. Read Full License 


\section{Abstract \\ Background}

The non-prescription use of antibiotics is a major challenge faced by all nations. The practice is pronounced in developing and low-income countries where legislation and regulations are weak. The present study assessed the non-prescription use of antibiotics and associated factors in Ambo town, West Shoa, Oromiya, Ethiopia.

\section{Methods}

Institutional based cross-sectional study design supported with the qualitative study was conducted in Ambo town from February 1 to March 1, 2020. Data were collected using a pre-tested semi-structured questionnaire and in-depth interview guide questions. Simple random sampling was used to select retail outlets and systematic random sampling to select study participants. The data analysis was done using SPSS and univariate and multivariate binary logistic regression analysis were performed to identify factors associated with non-prescription use of antibiotics. Thematic framework analysis was applied for the qualitative data.

\section{Results}

From a 421 study sample, a total of 399 participants were interviewed with a $94.8 \%$ response rate. Among the study participants 214 (53.6) were males, 228 (57.1\%) were married, 191(47.9\%) were orthodox by religion and, 343(86\%) were Oromo by ethnicity. One hundred seventy two (43.1\%) $95 \% \mathrm{Cl}=$ $(38.6,48.1)$ of the participants had used non prescribed Antibiotics. Being male [AOR $=2.2195 \% \mathrm{Cl}$ $1.276,3.835]$, residing in rural area $[A O R=3.659,95 \% \mathrm{Cl} 1.479,9.054]$, holding Diploma[AOR $=0.120,95 \%$ $\mathrm{Cl} 0.025,0.591]$, and hold BSC Degree [AOR $=0.050,95 \% \mathrm{Cl} 0.007,0.378]$, and being farmer [AOR $=0.034$, $95 \% \mathrm{Cl} 0.004,0.285]$ showed significant association with the non prescription use of Antibiotics.

\section{Conclusion}

This study concluded that the non-prescription use of antibiotics 172 (43.1\%) was relatively high. Being male, residing in a rural area, holding a diploma, BSc Degree, and being a farmer were significantly associated with non-prescription use of antibiotics. So West Shoa Zone regulatory body should actively focus on the prevention of non-prescription use of Antibiotics through health communication and public awareness on the demerits of non-prescription use of Antibiotics

\section{Background}


Antibiotics are widely used drugs to treat bacterial infections and they are the most frequently prescribed medicines worldwide. Between 2000 and 2010, the consumption of antibiotics increased from approximately 50 billion to 70 billion standard units [1]. Their use is also associated with more harm than good when not used properly. Non-prescription sale and use of antibiotics are prevalent in all communities of the world [2]. Non-prescribed use of antibiotics increases irrational use, especially with most infections in the community such as respiratory tract infections viral in origin [3]. Irrational use of antibiotics is a key driver in the emergence and spread of antimicrobial resistance (AMR), which is now seen as a major threat to global public health [4].

The impact of antibacterial resistance has negative consequences on health and the economy. Drugresistant infections cause approximately 700,000 deaths per year globally. If no intervention the number increase to 10 million by 2050, with associated costs as high as USD 100 trillion worldwide [5]. Many factors have been related to the emergence of AMR. People hold the view that medicine should be used in the event of any sickness or discomfort [6]. Socio-demographic characteristics including; sex, age, marital status, occupation, income, religion, residence, and educational status, chronic diseases [7], the severity of illness [8], and repeated exposure to disease [9] have been documented as determinants of nonprescribed anti-microbial drugs use [10]. Other variables such as previous experience with antibiotics, waiting time in health facilities and distance of health care facility, knowledge-related factors (drug awareness, adverse effect, previous exposure, and past successful anti-microbial drug use) $[8,11]$ have also been enlisted. The consequences of non-prescribed antimicrobial drug use include; adverse drug reactions and masking of underlying infectious processes [12]. On the other hand, irrational use of antibiotics can be short term treatment, inadequate dose, sharing of medicines, or stopping treatment upon the improvement of disease symptoms [13]. Antimicrobial-resistance is a major emerging global public health problem in communities with frequent non-prescribed antibiotic use [14].

Although globally antimicrobial resistance is an emerging threat to public health, the problem is more severe in developing countries like Ethiopia where the burden of infectious diseases is relatively greater and healthcare spending is low. In Ethiopia, over the counter (OTC) use of antibiotics in partial doses and without prescription are common practices, although the practice is not legal [15]. According to the study conducted in Ethiopia's Tigray region, the magnitude of non-prescribed antimicrobial use was $47.1 \%$ [16]. The misuse and overuse of antibiotics in Ethiopia coupled with weak regulatory mechanisms contributed to increasing antimicrobial resistance ranging from 0-100 \% [17].

In countries, like Ethiopia antibiotics are illegally purchased without medical prescriptions and very little effort has been made to tackle the situation. The role of pharmacists in contributing to healthcare remains debatable. Community pharmacists and drug stores are now seen as businessmen and retailers rather than health care providers. Self-medication with antibiotics is a universal problem and variations regarding such practices are obvious around the globe [18]. The practice cuts across culture, gender, age, health status, social status, race, and occupation [19]. Therefore, this study aims to assess the magnitude of non-prescription sale of antibiotics and associated factors in Ambo Town, West Shoa Zone, Oromiya, Ethiopia 2020. 


\section{Methods And Materials \\ Study area}

The study was conducted in Ambo town, West Shoa Zone, Oromiya Regional State, Ethiopia. The town is located $114 \mathrm{~km}$ from the capital Addis Ababa. Based on the 2007 Ethiopian national population and housing census, the population of the town is projected to be about 86,405 . The town has both private and governmental pharmacies and drug stores where the prescription-only drugs and over the counter drugs are dispensed to the customers.

\section{Study Design and period}

A drug retail outlet based cross-sectional study was conducted from February 1 to March 1, 2020.

\section{Study population}

All the people who bought antibiotics, from randomly selected pharmacies and drug stores (drug retail outlet) in Ambo Town during the study period.

\section{Sample size determination}

The sample size was calculated using a single population proportion formula; considering a $5 \%$ margin of error, the proportion of non-prescription use of antibiotics was $47.1 \%$ obtained from a previous study done in Tigray [16], Ethiopia, 95\% confidence interval, and 10\% possible non-response rate.

$$
n=z^{2} a_{/ 2} \times p(1-p) / w^{2}
$$

Where: $\mathrm{n}=$ Sample size.

$p=$ proportion of irrational use and non-prescription sale of antibiotics

$\mathrm{W}=$ maximum allowable error (margin of error $)=0.05$

$Z=$ value of the standard normal distribution (Z-statistic) at a $95 \%$ confidence level which was 1.96. 1.96 $x 0.471 \times 0.529 / 0.05^{2}=383$

The sample size for the qualitative study was based on the saturation of ideas.

\section{Sampling technique and procedures}

A simple random sampling technique was used to select 10 out of 32 pharmacies and drug stores in the town. Then the history of the number of antibiotics purchasers in January 2020 was assessed for each 
selected pharmacy and drug store. Based on the history data systematic random sampling methods were used to select study participants from each selected pharmacy or drug store for every $3^{\text {rd }}$ purchaser at the exit. The first study subject was determined randomly by the lottery method. The sample size was allocated proportionally to each pharmacy or drug store.

Operational Definition

Non-prescription antibiotic use-non-prescription-based inappropriate antimicrobial use for the treatment of common infections without consulting a medical practitioner and any medical supervision

Drug retail outlet -A place used for the conduct of the drug sale, administering or dispensing, and licensed by the responsible body as a place wherein the practice of pharmacy may lawfully occur.

\section{Data collection tool and techniques}

Data were collected using a pre-tested and semi-structured questionnaire and in-depth interviews. The questionnaire was prepared in English and translated to Afaan Oromo and Amharic then back to English to check for consistency and completeness.

The exit interview was conducted at the pharmacies or drug stores immediately after a person purchased antibiotics after getting consent. The interview was conducted by trained nurses who could speak Afaan Oromo and Amharic.

In-depth interviews of sellers were conducted using open-ended interview guide questions to explore factors related to non-prescription use of antibiotics. The in-depth interview was supported by taperecording which took 25-30 min on average. All the interviews were taken at locations that were chosen by the respondents.

\section{Data quality control and management}

To ensure data quality, training on the topic, and purpose of the research, on how to approach study subjects and how to use the questionnaire was given for one day for the data collectors. A pre-test was conducted at pharmacy retail outlets found outside the study area to modify the questionnaire. The collected data were checked for completeness, accuracy, and clarity on a daily basis after data collection and correction measure was made before the next data collection.

\section{Data processing and analysis}

Coding and cleaning of data were performed for completeness and consistency. Data were entered into Epi-Info version 7.1 and exported to SPSS version 24 software package for analysis. Descriptive statistics are presented as frequencies and percentages. The bi-variate analysis was performed for each variable 
and those variables with a p-value less than 0.25 was a candidate for multiple binary logistic regression. The binary logistic regression model was used to check the association between outcome and independent variables. Crude Odds Ratio (OR) and Adjusted Odds ratio (AOR) with their $95 \%$ confidence interval $(\mathrm{Cl})$ was reported. All statistical significance was determined at a p-value less than 0.05 .

Qualitative data were analyzed using thematic framework analysis [20]. The following six steps were conducted:

1. Transcriptions were carried out from the audio-taped interviews;

2. All transcripts were repeatedly read to familiarize with the data;

3. After careful reading, codes were developed so that similar codes were grouped into categories.

4. A working analytical framework was developed while grouping similar codes into categories;

5. Data were summarized by category from each transcript using a matrix spreadsheet, a process called charting;

6. Interpreting the data was the last step. Findings from patients and health professionals were triangulated. This helps to the validity of the data and show conflicting views.

\section{Results}

\section{Socio-demographic characteristics of study participants}

Out of the 421 study sample, a total of 399 participants were interviewed with a $94.8 \%$ response rate. The mean age of study participants was 36.32 (SD \pm 16.32 ) years. Among the study participants, 214 (53.6) were males, 228 (57.1\%) were married, 191(47.9\%) were orthodox by religion and, urban residents 291(72.9). One-fourth of the participants were unable to read and write while the remaining completed at least primary school. Occupationally the majority of the respondents were merchants (22.8) followed by government (20.3) (Table 1).

Table 1: Socio-demographic characteristics of the study participants $(n=399)$. 


\begin{tabular}{|c|c|c|c|}
\hline Variables & Category & Frequency & Percentage \\
\hline \multirow[t]{2}{*}{ Sex } & Male & 214 & 53.6 \\
\hline & Female & 185 & 46.4 \\
\hline \multirow[t]{5}{*}{ Age Group in year } & $18-27$ & 143 & 35.8 \\
\hline & $28-37$ & 85 & 21.3 \\
\hline & $38-47$ & 79 & 19.8 \\
\hline & $48-57$ & 39 & 9.8 \\
\hline & $>57$ & 53 & 13.3 \\
\hline \multirow[t]{3}{*}{ Marital Status } & Single & 159 & 39.8 \\
\hline & Married & 228 & 57.1 \\
\hline & Others & 12 & 3 \\
\hline \multirow[t]{3}{*}{ Religion afflation } & Orthodox & 191 & 47.9 \\
\hline & Protestant & 175 & 43.9 \\
\hline & Muslim & 33 & 8.3 \\
\hline \multirow[t]{2}{*}{ Residence } & Urban & 291 & 72.9 \\
\hline & Rural & 108 & 27.1 \\
\hline \multirow[t]{5}{*}{ Educational Status } & Unable to read and write & 85 & 21.3 \\
\hline & Primary school & 99 & 24.8 \\
\hline & Secondary school & 86 & 21.6 \\
\hline & Diploma & 62 & 15.5 \\
\hline & Degree and above & 67 & 16.8 \\
\hline \multirow[t]{7}{*}{ Occupational status } & Government & 81 & 20.3 \\
\hline & Merchant & 91 & 22.8 \\
\hline & Farmer & 74 & 18.5 \\
\hline & Housewife & 42 & 10.5 \\
\hline & Student & 13 & 5.7 \\
\hline & Non employed & 21 & 5.3 \\
\hline & Day laborer & 63 & 15.8 \\
\hline
\end{tabular}

Others; Divorced and Widowed 


\section{Non-prescription antibiotic use}

The magnitude of non-prescription use antibiotic in the study area is $43.2 \%(95 \% \mathrm{Cl}: 38.2,48.1)$. Amoxicillin is the top drug purchased (43.6\%) without prescription and followed by its congeners Ampicillin (11.63). Surprisingly, Azithromycin, which is a new drug, is one of the top four antibiotics purchased without a prescription. Moreover, metronidazole also purchased without a prescription (Table2).

Table 2: Antibiotics purchase without prescription the Antibiotic use Ambo town, Oromiya, Ethiopia, 2020

\begin{tabular}{|lll|}
\hline Non prescription purchased Antibiotics & Frequency & Percent \\
\hline Amoxicillin & 75 & 43.6 \\
\hline Ampicillin & 20 & 11.63 \\
\hline Cotrimoxazole & 15 & 8.72 \\
\hline Azitromycin & 13 & 7.56 \\
\hline Metrinidazole & 10 & 5.81 \\
\hline Tinidazole & 7 & 4.07 \\
\hline Cloxacillin & 7 & 4.07 \\
\hline Augumentin & 6 & 3.48 \\
\hline Cephalexin & 5 & 2.9 \\
\hline Tetracycline & 4 & 2.32 \\
\hline Ciprofloxacin & 3 & 1.74 \\
\hline Erythromycin & 2 & 1.16 \\
\hline Chloraniphenicol & 2 & 1.16 \\
\hline Gyntamicin & 1 & 0.59 \\
\hline Cefixin & 1 & 0.59 \\
\hline Penicillin & 1 & 0.59 \\
\hline Total & 172 & 100 \\
\hline
\end{tabular}

\section{Reasons for non-prescription use of antibiotics}

In this study, one hundred seventy-two study participants were reported using antibiotics without prescription. The study participants were asked the reason for taking antibiotics without prescription while they were expected to use only prescribed ones. One hundred seven $(62.2 \%)$ of the participants use 
the non-prescribed antibiotics to save time, $111(64.5 \%)$ to save money, $111(64.5 \%)$ to get well soon, 64\% because of previous experience with the same disease which was successful, 110 (64\%) because they assume antibiotics can be purchased without a prescription in pharmacy or drug stores, and 93 (54.1\%) doctors are likely to prescribe the same type of antibiotics (Figure 1).

The key informants were asked for their opinion on the main reasons that drive for nonprescription use of Antibiotics and the majority of them mentioned the lack of health information and previous experience with the same disease.

"One of the main problems is long waiting time, so to save their time as well their money the majority of our customers asked for antibiotics without prescription" (36-year-old female, Key informant who is working in one drug store).

A 25-year-old male, who was working in one private pharmacy in-depth interview said: "I worked in this pharmacy which is located in Ambo as a pharmacist. Even if the majority of our customers are using the prescribed antibiotics there are also a large number of customers who requested for antibiotics without prescription and the probable reasons for the non-prescription use of antibiotics may be long waiting time at the clinic"

Another 37-year-old male during an in-depth interview stated: "I am working in the drug store as a druggist and also the owner of the drug store, almost 45 to $50 \%$ of our customers ask us to provide them antibiotics without prescription and the majority of them use that due to lack of awareness or lack of health information"

Bivariate and multivariate analysis of factors associated with non-prescription use of antibiotics

According to the results from bivariate binary logistic regression, factors that were associated with nonprescription use of antibiotics are sex, age, marital status, residence, educational status, occupational status, traveling time, type of transportation, and cost of transportation (Table-3).

Table 3: Bivariate Binary Logistic Regression analysis of factors associated with non-prescription use of Antibiotics in Ambo town, Oromiya, Ethiopia, 2020 ( $n=399)$. 


\begin{tabular}{|c|c|c|c|c|c|}
\hline \multirow[t]{2}{*}{ Variables } & \multirow[t]{2}{*}{ Category } & \multicolumn{2}{|c|}{$\begin{array}{l}\text { Non-prescribed } \\
\text { Antibiotic Use }\end{array}$} & \multirow[t]{2}{*}{ COR $(95 \% \mathrm{Cl})$} & \multirow[t]{2}{*}{$\begin{array}{l}\mathrm{P}- \\
\text { value }\end{array}$} \\
\hline & & Yes (\%) & No (\%) & & \\
\hline \multirow[t]{2}{*}{ Sex } & Male & $99(57.6)$ & $115(50.7)$ & $1.32(0.89,1.97)$ & $0.172 *$ \\
\hline & Female & $73(42.4)$ & $112(49.3)$ & 1 & \\
\hline \multirow{5}{*}{ Age in year } & $18-27$ & $74(43)$ & $69(30.4)$ & 1 & \\
\hline & $28-37$ & $40(23.3)$ & $45(19.8)$ & $3.30(1.63,6.69)$ & $0.001 *$ \\
\hline & $38-47$ & $30(17.4)$ & $49(21.6)$ & $2.74(1.28,5.83)$ & $0.009 *$ \\
\hline & $48-57$ & $15(8.7)$ & $24(10.6)$ & $1.88(0.87,4.08)$ & $0.108 *$ \\
\hline & $>57$ & $13(7.6)$ & $40(17.6)$ & $1.92(0.78,4.72)$ & $\begin{array}{l}0.154- \\
\star\end{array}$ \\
\hline \multirow[t]{3}{*}{ Marital Status } & Single & $80(46.5)$ & $79(34.8)$ & 1 & \\
\hline & Married & $84(48.8)$ & $144(63.4)$ & $0.58(0.38,0.87)$ & $0.009 *$ \\
\hline & Others & $8(4.7)$ & $4(1.8)$ & $1.98(0.57,6.82)$ & 0.282 \\
\hline \multirow[t]{2}{*}{ Residence } & Urban & 114(66.3) & 177(78) & 1 & \\
\hline & Rural & $58(33.7)$ & $50(22)$ & $1.80(1.15,2.81)$ & $0.010 *$ \\
\hline \multirow[t]{5}{*}{ Educational Status } & $\begin{array}{l}\text { Unable to read } \\
\text { and write }\end{array}$ & $40(23.3)$ & 45(19.8) & 1 & \\
\hline & $\begin{array}{l}\text { Elementary } \\
\text { school }\end{array}$ & $45(26.2)$ & $54(23.8)$ & $0.94(0.52,1.68$ & 0.828 \\
\hline & $\begin{array}{l}\text { Secondary } \\
\text { school }\end{array}$ & $46(26.7)$ & $40(17.6)$ & $1.29(0.71,2.36)$ & 0.401 \\
\hline & Diploma & $25(14.5)$ & $37(16.3)$ & $0.76(0.39,1.47)$ & 0.417 \\
\hline & $\begin{array}{l}\text { Degree and } \\
\text { above }\end{array}$ & $16(9.3)$ & $51(22.5)$ & $0.35(0.17,0.71)$ & $0.004 *$ \\
\hline \multirow[t]{7}{*}{ Occupational status } & Government & 23(13.4) & $58(25.6)$ & 1 & \\
\hline & Merchant & $34(19.8)$ & $57(25.1)$ & $1.50(0.79,2.86)$ & 0.213 \\
\hline & Farmer & 19(11) & $55(24.2)$ & $0.87(0.43,1.77)$ & 0.704 \\
\hline & Housewife & 23(13.4) & 19(8.4) & $3.05(1.40,6.63)$ & $0.005^{\star}$ \\
\hline & Student & $14(8.1)$ & $13(5.7)$ & $2.72(1.11,6.65)$ & $0.029 *$ \\
\hline & Non employed & $14(8.1)$ & $7(3.1)$ & $5.04(1.80,4.10)$ & $0.002 *$ \\
\hline & Daily laborer & $45(26.2)$ & 18(7.9) & $6.30(3.04,3.07)$ & 0.000 * \\
\hline
\end{tabular}




\begin{tabular}{|llllll|} 
Traveling time in Min & $<15 \mathrm{~min}$ & $189(83.6)$ & $117(68)$ & $0.52(0.30,0.88)$ & $0.016^{*}$ \\
\cline { 2 - 6 } & 15-30min & $24(10.6)$ & $43(25)$ & $0.35(0.21,0.59)$ & $0.000^{*}$ \\
\cline { 2 - 6 } & $>30 \mathrm{~min}$ & $13(5.8)$ & $12(7)$ & & \\
\hline \multirow{2}{*}{ Type of transportation } & On foot & $101(58.7)$ & $74(32.6)$ & $2.93(1.94,4.43)$ & $0.000^{*}$ \\
& $\begin{array}{l}\text { Use own } \\
\text { transport }\end{array}$ & $2(1.2)$ & $5(2.2)$ & $0.86(0.16,4.53)$ & 0.857 \\
\cline { 2 - 6 } & Public transport & $69(40.1)$ & $65.2(148)$ & 1 & \\
\hline $\begin{array}{l}\text { Cost of travel for a single } \\
\text { trip in ETB }\end{array}$ & <6Birr & $70(30.8)$ & $33(19.2)$ & 1 & \\
\cline { 2 - 6 } & $>$ >Birr & $157(69.2)$ & $139(80.8)$ & $1.34(0.90,1.99)$ & $0.154 *$ \\
\cline { 2 - 6 }
\end{tabular}

*=P-value $\leq 0.25 \mathrm{COR}=$ crude odds ratio, $\mathrm{Cl}=$ confidence interval

In the multivariate binary logistic regression marital status, residence (rural), sex (male), educational status (diploma and degree holder), and occupation (farmer) were found to be statistically significant (Table-4).

Table 4: Multivariable logistic regression analysis and associated factors for non-prescription use of Antibiotics in Ambo town, Oromiya, Ethiopia, 2020 ( $n=399)$. 


\begin{tabular}{|c|c|c|c|c|c|}
\hline \multirow[t]{2}{*}{ Variables } & \multirow[t]{2}{*}{ Category } & \multicolumn{2}{|c|}{$\begin{array}{l}\text { Non-prescribed } \\
\text { Antibiotic use }\end{array}$} & \multirow[t]{2}{*}{$\operatorname{AOR}(95 \% \mathrm{Cl})$} & \multirow[t]{2}{*}{ P-Value } \\
\hline & & Yes (\%) & No (\%) & & \\
\hline \multirow[t]{3}{*}{ Marital status } & Single & $80(46.5)$ & $79(34.8)$ & 1 & \\
\hline & Married & $84(48.8)$ & 144(63.4) & $1.21(0.53,2.79)$ & 0.653 \\
\hline & Others & $8(4.7)$ & $4(1.8)$ & $8.73(1.61,7.29)$ & $0.012^{\star \star}$ \\
\hline \multirow[t]{2}{*}{ Residence } & Urban & $114(66.3)$ & $177(78)$ & 1 & \\
\hline & Rural & $58(33.7)$ & $50(22)$ & $3.66(1.48,9.05)$ & $0.005^{\star \star}$ \\
\hline \multirow[t]{2}{*}{ Sex } & Male & 99(57.6) & 115(50.7) & $2.21(1.28,3.84)$ & $0.005^{\star \star}$ \\
\hline & Female & $8(4.7)$ & $4(1.8)$ & 1 & \\
\hline \multirow[t]{5}{*}{ Educational Status } & uneducated & $40(23.3)$ & $45(19.8)$ & 1 & \\
\hline & Primary school & $45(26.2)$ & $54(23.8)$ & $0.47(0.21,1.08)$ & 0.075 \\
\hline & Secondary school & $46(26.7)$ & 40(17.6) & $0.89(0.39,2.03)$ & 0.783 \\
\hline & Diploma & $25(14.5)$ & $37(16.3)$ & $0.12(0.03,0.59)$ & $0.009 * \star$ \\
\hline & Degree & $16(9.3)$ & $51(22.5)$ & $0.05(0.01,0.38)$ & $0.004^{\star \star}$ \\
\hline \multirow[t]{7}{*}{ Occupation } & Government & 23(13.4) & $58(25.6)$ & 1 & \\
\hline & Merchant & $34(19.8)$ & $57(25.1)$ & $0.19(0.03,1.23)$ & 0.082 \\
\hline & Farmer & 19(11) & $55(24.2)$ & $0.03(0.00,0.29)$ & $0.002^{\star *}$ \\
\hline & Housewife & $23(13.4)$ & $19(8.4)$ & $0.36(0.05,2.88)$ & 0.337 \\
\hline & Student & $14(8.1)$ & $13(5.7)$ & $0.18(0.02,1.37)$ & 0.097 \\
\hline & Non employed & $14(8.1)$ & $7(3.1)$ & $2.64(0.63,1.09)$ & 0.187 \\
\hline & Day laborer & $45(26.2)$ & $18(7.9)$ & $0.34(0.05,2.23)$ & 0.260 \\
\hline
\end{tabular}

**=P-value $<0.05$ AOR adjusted odds ratio, $\mathrm{Cl}$ confidence interval. Others=divorced and widowed

\section{Discussion}

The current study has assessed the non-prescription use of antibiotics and associated factors in Ambo Town. The study findings revealed that $172(43.1 \%)$ with $(95 \% \mathrm{Cl}: 38.3,47.9)$ had used non-prescribed antibiotics in the study period. This study finding is consistent with previous studies conducted in Asmara Eretria (45.1\% ) [21] and Saudi Arabia (48.5\%) [22]. But the finding of this study is higher than the 
findings reported from South Ethiopia (14.5\%) [23], Northwest Ethiopia 23.3\% [24], United Arab Emirate (31.7\%) [25], and Southwestern Ethiopia (39\%) [26]. The difference in the prevalence of non-prescription use of antibiotics might be due to the differences in awareness of the communities, and definitions used in the studies. However, the results on non-prescription use of antibiotics in the current study are lower than the findings of researches conducted in Zambia (97\%) [27], India (66.7\%) [28], and Riyadh (77.6\%) [29]. The prevalent trend of non-prescription use of antibiotics in the developing world has been associated with a lack of access to health care, availability of antibiotics as Over-the-Counter (OTC) drugs, poor regulatory practice, and the relatively higher prevalence of the infectious disease. The differences could also be because of the country's laws on drug procurement or the law enforcement policies of the drug regulatory agencies of the countries where the studies were conducted.

The independently associated factors with non-prescribed antibiotics use were being male, residing in a rural area, divorced and widowed, and hold a diploma and BSc degree. The odds of non-prescription use of antibiotics among male respondents were 2.213 times higher than female respondents. Similar findings have been evidenced in Indonesia [30], Asmara Eretria [21], Central Zone of Tigray, Ethiopia [31], Saud Arabia [32]. This finding was contrary to other studies done in Nigeria [33], and the United Arab Emirates [34]. This difference may be due to the current study context, males have better health-seeking behavior compared to their counterparts.

The odds of non-prescription use of antibiotics among rural dweller respondents were three times more likely as compared to urban residing respondents. This study was similar to the study conducted in Nigeria [35]. Furthermore, the divorced and widowed were nine times more likely to use non-prescribed antibiotics than those who are single.

The finding of this study also showed that level education has significant association with nonprescription use of antibiotics. Holding Diploma and BSc degree decreases the odds of non-prescribed antibiotics use by $88 \%$, and $95 \%$ respectively as compared to those uneducated. This finding was similar to the studies conducted in Saud Arabia [32]. However, this finding was not in line with the study finding in Rwanda [36].

Regarding the occupational status, farmers were $96.6 \%$ less likely to use the non-prescribed antibiotics as compared to those who are government employees. This study finding is similar to studies conducted in the United Arab Emirates[34]. However, the current study was contrary to the studies conducted in Sudan which showed professionals have better incomes and thus can afford to pay for health expenses [37].

\section{Limitation Of The Study}

Triangulation of data collection methods (both quantitative and qualitative) is the strength of this study while most previous studies were used only quantitative or qualitative study design alone. Lack of temporally relationship and limitation related to self-report are the two common limitations of the study. 


\section{Conclusions}

This study revealed that the majority of the respondents practiced the non-prescription use of antibiotics. These groups associated with the non-prescription use of antibiotics were mainly male, residing in rural areas, others (divorced and widowed), diploma and degree holders as well as farmers. The findings emphasize the need to form and deliver comprehensive and multifaceted interventions such as providing tailored education to the public to improve their knowledge about the demerits of using antibiotics without the prescription. Moreover, to improve their attitude towards utilizing a non-prescription antibiotic, it is very important to adopt a strong and explicit line of action on the accessibility of antibiotics without a prescription from any drug retail outlets.

\section{Abbreviations}

AMR: Antimicrobial resistance; OTC: Over the counter; COR: Crude odds ratio; AOR: Adjusted odds ratio; Cl: Confidence interval; SD: Standard deviation; SPSS: Statistical Package for Social Science; USD: United States Dollar

\section{Declarations}

\section{Ethics Approval and consent to practice}

This study was approved by the ethical committee of Rift Valley University with approval number RVUSop217/2020. A written informed consent was also obtained from the study participants before commencing the study. Participant's information was kept confidential.

\section{Consent for publication}

Not applicable

\section{Availability of data and materials}

The datasets used and/or analyzed during the current study are available from the corresponding author on reasonable request.

\section{Competing interest}

The authors declare that they have no competing interests

\section{Funding}

This article is the outcome of an in-house financially non-supported study.

\section{Authors' contribution}


All authors have directly participated in the planning, data collection supervision as well as writing and drafting of the manuscript and read and approved the final version.

\section{Acknowledgments}

The authors would like to acknowledge all the study participants. The authors would also like to acknowledge the school of public health RVU for their unreserved support.

\section{References}

1. Van Boeckel TP GS, Ashok A, Caudron Q , Grenfell BT, Levin SA, et al. : Global antibiotic consumption 2000 to 2010: an analysis of national phar- maceutical sales data. . Lancet Infect Dis 2014, 14(8):742-750.

2. Ofori-Asenso R, Agyeman AA: Irrational Use of Medicines-A Summary of Key Concepts. Pharmacy (Basel) 2016, 4(4).

3. Gonzales R BJG, Besser R.E, Cooper R.J, Hickner J.M, Hoffman J.R, et al: Principles of appropriate antibiotic use for treatment of acute respiratory tract infections in adults. Annals of Internal Medicine 2001; 134(6): 479-86, 134(6):479-486.

4. Kalungia AC, Burger J, Godman B, de Oliveira Costa J, Simuwelu C: Non-prescription sale and dispensing of antibiotics in community pharmacies in Zambia. Expert review of anti-infective therapy 2016, 14

5. Lundborg AMaCS: Drivers of Irrational Use of Antibiotics in Europe. Int J Environ Res Public Health 2019.

6. Karki BSDaMB: Factors associated with irrational use of drugs among the community dwellers in Kabesa, Punakha, Bhutan. 2018.

7. Berzanskyte A VR, Haaijer-Ruskamp F, Gurevicius R, Grigoryan L.: Self-medication with antibiotics in Lithuania. Int J Occup Med Environ Health 2006, 19(4):246-253.

8. Ocan M OE, Bwanga F, Akena D, Richard S, Ogwal-Okeng J, et al.. Household antimicrobial selfmedication: a systematic review and metaanalysis of the burden, risk factors and outcomes in developing countries. BMC Public Health 2015, 15(1):1.

9. Afzal S SF, Hayat T, Sherwani UK, Siddiqui UA, Ishtiaq Q, et al.: The Determinants of Self Medications. . Annals of King Edward Medical University 2013, 19(1):73-74.

10. A. A: Self Medication, Drug Dependency and Self-Managed Health Care-A Review INTECH Open Access Publisher 2012.

11. Ocan M, Bwanga F, Bbosa GS, Bagenda D, Waako P, Ogwal-Okeng J, Obua C: Patterns and Predictors of Self-Medication in Northern Uganda. PLoS One 2014, 9(3):e92323.

12. Esimone $\mathrm{CO} \mathrm{NC}$, Udeogaranya OP. . Utilization of antimicrobial agents with and without prescription by out-patients in selected pharmacies in South-eastern Nigeria. . Pharm World Sci ; 2007, 29(6):655-660. 
13. Papafragos $C$ ea: Self-medication with antibiotics in rural population in Greece: a cross-sectional multicenter study. . BMC Fam Pract 2010, 11(1):58.

14. Morgan DJO, I.N.; Laxminarayan, R.; Perencevich, E.N.; Weisenberg, S. . Non-prescription antimicrobial use worldwide: A systematic review. Lancet Infect Dis 2011, 11:692-701.

15. Okeke IN KK, Bhutta ZA, Duse AG, Jenkins P, O'Brien TF, et al., . Antimicrobial resistance in developing countries. Part II: strategies for containment. . Lancet Infect Dis 2005 5(9):568-580.

16. Gebrekirstos NH, Workneh BD, Gebregiorgis YS, Misgina KH, Weldehaweria NB, Weldu MG, Belay HS: Non-prescribed antimicrobial use and associated factors among customers in drug retail outlet in Central Zone of Tigray, northern Ethiopia: a cross-sectional study. Antimicrobial Resistance and Infection Control 2017, 6:70-70.

17. Gebretekle GB, Serbessa MK: Exploration of over the counter sales of antibiotics in community pharmacies of Addis Ababa, Ethiopia: pharmacy professionals' perspective. Antimicrobial Resistance and Infection Control 2016, 5(1):2.

18. Sisay M, Mengistu G, Edessa D: Epidemiology of self-medication in Ethiopia: A systematic review and meta-analysis of observational studies. BMC pharmacology \& toxicology 2018, 18.

19. Ofori-Asenso R, Agyeman AA: Irrational Use of Medicines-A Summary of Key Concepts. Pharmacy (Basel) 2016, 4(4):35.

20. Gale NK HG, Cameron E, Rashid S, Redwood S: Using the framework method for the analysis of qualitative data in multi-disciplinary health research. BMC Medical Research Methodology 2013, 13(1):117.

21. Yonatan Ateshim1* BB, Feruz Major1, Youel Emun1, Biruck Woldai1, Ismail Pasha1, Eyasu Habte2, Russom3 aM: Prevalence of self-medication with antibiotics and associated factors in the community of Asmara, Eritrea: a descriptive cross sectional survey. 2019 19:726.

22. Belkina T AWA, Eltom EH, Tadjieva N, Kubena A, Vlcek J. : Antibiotic use and knowledge in the community of Yemen, Saudi Arabia, and Uzbekistan. J Infect Dev Ctries 2014, 8(04):424-429.

23. Wabe NT AD, Angamo MT.: Self-medication with antibiotics and antimalarials in the community of Silte zone, South Ethiopia. TAF Prev Med Bull 2012, 11(5):529-536.

24. Mihretie TM: Self-Medication Practices With Antibiotics Among Urban Dwellers Of Bahir Dar Town, North West Ethiopia. 2014.

25. Abduelmula R A, Amna M Othman 1, Zakieh M Abuelkhair1, Mariam M Ghazal1, Sawsan B Alzouobi1, Mohamed E El Zowalaty 2: Prevalence Of Self-Medication With Antibiotics Among Residents In United Arab Emirates. Infection and Drug Resistance downloaded from https://wwwdovepresscom/ by 19619022317 on 23-Jul-2020.

26. Suleman S, Ketsela A, Mekonnen Z: Assessment of self-medication practices in Assendabo town, Jimma zone, southwestern Ethiopia. Research in Social and Administrative Pharmacy 2009, 5(1):7681.

27. Kalungia AC BJ, Godman B, Costa JO, Simuwelu C. : Non-prescription sale and dispensing of antibiotics in community pharmacies in Zambia. Expert Rev Anti-Infect Ther 2016, 14(12)::1215- 
1223.

28. Shet A SS, Forsberg BC.: Pharmacy-based dispensing of antimicrobial agents without prescription in India: appropriateness and cost burden in the private sector. Antimicrob Resist Infect Control 2015, 4(1):55.

29. Abdulhak AAB ATM, Almansor MA, Almohaya MS, Onazi AS, Marei MA, et al. . Non prescribed sale of antibiotics in Riyadh, Saudi Arabia: a cross sectional study. . BMC Public Health 2011, 11(1):1.

30. Usman Hadi a DODb, Endang Sri Lestari c,Nico J. Nagelkerke d,: Survey of antibiotic use of individuals visiting public healthcare facilities in Indonesia. 2008 12:622-629.

31. Negash Hadera Gebrekirstos1 BDW, Yosef Sibhatu Gebregiorgis3*, Kebede Haile Misgina3, Negassie Berhe Weldehaweria3 MGWaHSB: Non-prescribed antimicrobial use and associated factors among customers in drug retail outlet in Central Zone of Tigray, northern Ethiopia: a cross-sectional study 2017.

32. Mohammed A Al-Qahtani1 HSA, Abdullah A Al-Qahtani1, Abdullah M Alshahrani1, Hani A Alghamdi1, Musa S Althwayee2, Ahmed A Alzahrani: Self-medication with antibiotics in a primary care setting in King Khalid University Hospital, Riyadh, Saudi Arabia. 2018, 25.

33. Deborah Tolulope Esan AAF, Opeoluwa Esther Odesanya,Theophilus Olaide Esan,3 Elizabeth Funmilayo 0jo,1 and Charles Oluwafemi Faeji4: Assessment of Self-Medication Practices and Its Associated Factors among Undergraduates of a Private University in Nigeria. Journal of Environmental and Public Health 2018.

34. Abduelkarem AR OA, Abuelkhair ZM, Ghazal MM, Alzouobi SB, El Zowalaty ME: Prevalence Of SelfMedication With Antibiotics Among Residents In United Arab Emirates. 2019.

35. I. S. Abdulraheem* AAaAAF: Self-medication with Antibiotics: Empirical Evidence from a Nigerian Rural Population. British Journal of Pharmaceutical Research 2016, 11(5).

36. Jacques Tuyishimire1 FO, Adebisi Yusuff Adebayo3, Fabrice Humura4,\&, Don Eliseo Lucero-Prisno III5,6: Assessment of self-medication practices with antibiotics among undergraduate university students in Rwanda. Pan African Medical 2019, 33.

37. Arwa H. A.Elhada*1 IBE, Mahmoud M. E. Mudawi3,4: Patterns of self-medication with antibiotics in Khartoum State, Sudan Article in World Journal of Pharmaceutical Research 2014.

\section{Figures}




\section{Reasons reported by key informants for non-prescripion use of antibiotics}

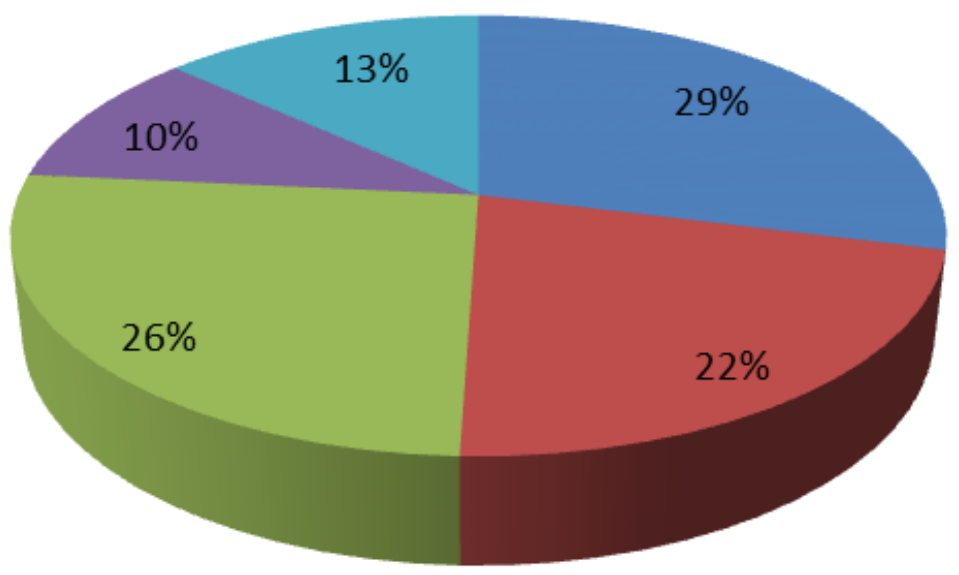

- Long waiting time at clinic or hospital

Distance of the clinic or hospital is contributing

Lack of awareness

- Side effect of previously prescribed antibiotic

- Disease condition like chronic diseases

Figure 1

Reasons reported by key informants for nonprescription use of antibiotics in Ambo town, West Shoa, Oromiya, Ethiopia 2020. 